\title{
Celtic Tiger Ireland and the Car as a Liminal Space: Movement and Paralysis in Gerard Donovan's Country of the Grand
}

\author{
Alessandra Boller \\ Philipps-University Marburg, Germany \\ alessandra.boller@staff.uni-marburg.de
}

Copyright (c) 2017 by Alessandra Boller. This text may be archived and redistributed both in electronic form and in hard copy, provided that the author and journal are properly cited and no fee is charged for access.

\begin{abstract}
This article discusses three short stories published in Gerard Donovan's Country of the Grand (2008). It reads one of the short story collection's most prominent leitmotifs, the car, as a liminal space and a heterotopia of crisis. Furthermore, the article aims at linking these two concepts to ideas about Irish identity and the historical and cultural context of Celtic Tiger Ireland and it draws on a particular theoretical framework: Turner's concept of the liminal period and the Foucauldian heterotopia of crisis. In Donovan's short stories, the car is turned into an ambiguous symbol since it carries various meanings and connotations. It is a means by which people move and cross boundaries, which should enable progress and provide connections between places and persons but it is also a space in which characters sit still and seem isolated and static. Hence, this seemingly simple image provides insights about a tension arising between movement and paralysis which Donovan, through his use of symbols and synecdoches, describes as central to Celtic Tiger Ireland and which thus also becomes crucial for his short stories.
\end{abstract}

Key Words. Irish Short Fiction, Gerard Donovan, Celtic Tiger Ireland, Liminality, Identity,

Heterotopias

Resumen. El presente artículo examina tres historias cortas de la colección Country of the Grand (2008), del escritor irlandés Gerard Donovan. Se centra muy especialmente en la consideración de uno de los más importantes símbolos de los relatos, el coche, interpretándolo como un espacio liminar y como una heterotopía de crisis. Se pretende además unir estos dos conceptos con ideas relacionadas con la identidad irlandesa, dentro del contexto cultural e histórico del llamado Tigre Celta. Este trabajo se basa por tanto en un marco teórico desarrollado por Victor Turner ("periodo liminar") y Michel Foucault ("heterotopía de crisis"). En las historias cortas de Donovan, el coche se transforma en un símbolo ambivalente puesto que lleva consigo diversos mensajes y connotaciones. Es un medio por el que la gente se mueve y con el cual se cruzan fronteras, lo cual debería facilitar el progreso y proporcionar elementos de conexión entre sitios y gentes, pero también es un espacio en el que los individuos permanecen quietos y parecen aislados y estáticos. De ahí que esta imagen, aparentemente simple, pueda proporcionar 
valiosas consideraciones sobre la tensión existente entre movimiento y parálisis. Será este aspecto central el que Donovan destaque en sus relatos a la hora de describir el Tigre Celta, utilizando para ello las figuras del símbolo y la sinécdoque.

Palabras clave. Relatos irlandeses, Gerard Donovan, la Irlanda del Tigre Celta, liminalidad, identidad, heterotopías

\section{Introduction}

But there are so many places and so many cars. Across the country, from Donegal to Tipperary and down to Kerry, the roads have begun to fill, coast roads, roads through small towns, roads widening into the midlands, narrowing into cities, red signs, yellow signs, bump ahead, one hundred this, fifty that. So much to notice with a shoe on a pedal, a hand on the wheel, an eye on the road. (Donovan 2008: 71)

The experience of the journey is central to literature. Any text is essentially a journey and a quest. Roads are ridden or driven along by characters which embark on journeys from here to there. Travelling is opposite of staying put. (Bâdalescu 2012: n.p.)

Even though the validity of Dana Bâdalescu's statement cannot be denied, literary journeys often consist of more than a departure from an origin and an arrival at a specified destination. There are metaphorical journeys or psychological ones and some characters are caught in conflicts between moving on and staying put. The short stories analysed in the following article are texts in which various characters' physical journeys contrast with their mental or social states and identities.

The three stories this article focuses on were published in the short story collection Country of the Grand (2008), written by Irish émigré author Gerard Donovan, whom Marie Mianowski regards as part of the "first wave of post Celtic Tiger writers" (2016: 5). Donovan was born in Wexford in 1959 and most of the 13 short stories collected in Country of the Grand were written while the author was living in Germany and the USA (Cardin 2014: 160). He had already published poetry collections and novels before turning to short fiction but in his well received collection, Donovan revisits his home country for the first time in his literary career. All stories are connected by certain motifs, themes and settings (e.g. archaeology and the search for the past) and the collection can thus also be identified as a short story cycle.

The following article analyses the most prominent leitmotif, the car, which becomes a liminal space and a heterotopia of crisis for its occupants. The car can generally be read as a symbol of consumption or social status; it can be a fetish and stands for fast movement. In the selected short stories, however, this means of transport has to be read in terms of space, time and crisis. Many of Donovan's characters embark on journeys by car and this (form of) travelling also often becomes a catalyst for a character's life-changing epiphany. Thus, the characters' journeys also signify metaphorical or mental changes since they go on a quest to find solutions, answers or stability - also with regard to identity.

Most of these stories are set in Celtic Tiger Ireland, but Ireland at the time of its economic boom and "spectacular growth" (Battel 2003: 100) is more than a mere background setting. Both Ireland and Irish society are depicted as being in a state of crisis even though (or maybe because) the Republic is wealthier than ever before. The Celtic Tiger was not solely an economic phenomenon; it can hardly be disentangled from issues of national or cultural identity. ${ }^{1}$ Jason Buchanan explains that the Celtic Tiger was born out of a "tension between the 
ideas of Irish exceptionalism and a growing desire for a more worldly or modern Ireland" and thus it "came to be understood as the culmination of, or escape from, Irish history" (2009: 303). Hence, the boom (which lasted from 1992 to 2001 and was finally replaced by the 2008 world economy crisis) cannot be disregarded when talking about Irish society and identity at the end of the twentieth and the beginning of the twenty-first century. The changes that affected individual people and society in general were massive and manifold and occurred at a quick pace. Buchanan aptly summarises the image the term Celtic Tiger often evokes by stating that it has become "the password for a newness that attempts to separate old from new, local from global, and past from present" (2009: 300). However, this "newness" is not entirely without negative connotations and effects since it also produced problems almost unthought of before. The discomfort that also haunts Donovan's characters seems to be due to the difficulties they experience in adjusting to a new situation since the "social and cultural issues created by wealth were unfamiliar to most Irish politicians and economists" (Buchanan 2009: 304).

According to Joseph O'Connor, Donovan's collection shows a "society that tried to run before it learned to walk"; a "sense of having come too far, of something precious being lost" (2008: n.pag.) permeates the stories. Bertrand Cardin also draws on O'Connor's ideas and attests the collection to be a "chronicle of a collapse foretold" (2014: 163). Donovan's Ireland is not a rural idyll or a cliché Ireland but a wealthy and more modern nation. However, the new opportunities provided in Celtic Tiger Ireland may also be held responsible for an emerging "battle over cultural self-identification" (Buchanan 2009: 304). Issues of cultural or national identity of course also affected the individual person's identity and this is mirrored and elaborated on in Donovan's stories. Hence, the title of this collection turns out to be ironical ${ }^{2}$ because nothing seems to be "grand" in the Ireland of Donovan's short stories and, like in most generic short stories, moments of (personal) crisis prevail. These crises are often linked to and occur during specific journeys or are directly brought about by them. Movement, however, does not always signify an escape from crisis and the arrival at a specific destination. Instead, Donovan depicts characters that are lost, that try to (re)construct an identity either according to an imagined new state by being "modern" (whatever that means for them) and cosmopolitan or by attempting to return to the past.

Movement juxtaposed to stasis stands at the centre of many of these stories. The collection depicts characters running and driving across the country, coming to a standstill in traffic jams (although Ireland's improved and improving infrastructure is often alluded to) or constructing roads. This image is often connected to a search for the past; time and space are inseparably connected here. Interestingly, many of the stories are not set in the capital Dublin but in Galway or in cars driving towards this city. ${ }^{3}$ However, cars should not be regarded as settings only: this article reads the car as a liminal space and a heterotopia of crisis, linking these two concepts to notions of Irish identity and the historical and cultural context of Celtic Tiger Ireland. Furthermore, it draws on Turner's concept of the liminal period and the Foucauldian heterotopia. In Donovan's short stories, the car constitutes an ambiguous and complex symbol since it carries various meanings and connotations. It is a means by which people move and cross boundaries, which should enable progress and provide connections between places and persons, but it is also a "metal box" (Cardin 2014: 166) in which they sit still and seem isolated and static. This seemingly simple image provides insights about a tension between movement and paralysis which is central to Celtic Tiger Ireland and Donovan's stories. Thus, focusing on the limited space of the car and the transient heterotopias constituted in the narratives allows for a discussion of specific crises in the lives of literary characters which eventually can be regarded as synecdoches for Irish society's insecurities during the Celtic Tiger years.

\section{Liminality and Heterotopias}


Generally speaking, liminality signifies a threshold, a state of in-betweenness and of becoming (Nordin and Holmsted 2009: 7). Arnold van Gennep coined the term when writing about a class of rituals with three distinctive moments (separation, margin, aggregation) in Rites de Passage (1909). Victor Turner based his famous article "Betwixt and Between: The Liminal Period in Rites de Passage" on van Gennep's work. Turner focuses on liminal periods within the rituals of small-scale societies and, according to him, rites of passage are transitions between fixed and stable conditions. Transition is understood as a process and a becoming, a transformation (1999: 234): "During the ... liminal period, the state of the ritual subject ("the passenger") is ambiguous; he passes through a realm that has few or none of the attributes of the past or coming state" (Turner 1999: 235). Furthermore, liminality and rites of transition are often linked to seclusion, to a temporary withdrawal from society. During such a liminal period, the concerned people's condition can be described in terms of confusion, ambiguity and paradox. According to Turner, transitional beings possess nothing but he also emphasises positive connotations: liminality is regarded as the "realm of primitive hypothesis where there is a certain freedom to juggle with the factors of existence" (1999: 241). Thus, it is also a "stage of reflection" (Turner 1999: 240) and the liminal period is not only about culturally defined life crises but also about a change from one state to another. ${ }^{4}$ Turner stresses the spatial dimension of rites of passage by explaining that the "passage from one social status to another is often accompanied by a parallel passage in space, a geographical movement from one place to another" (1982: 25; see also Hetherington 1996: 36). As will be explained in the following sections, all these aspects of space and identity are inseparably connected and apply to Donovan's characters. The passage in space and the partial isolation of the characters is underlined by the implementation of the above mentioned leitmotif, the car.

In this context, the connection of Turner's ideas to a different (spatial) concept, the Foucauldian heterotopia, leads to interesting insights. In "Of Other Spaces. Heterotopias", Michel Foucault claims that all societies constitute counter-sites which he labels heterotopias of deviance and of crisis. The latter ones are reserved for people who are, in relation to society, in a state of crisis. They are spaces of otherness, neither here nor there and also linked to "slices in time" (Foucault 1984: 6): they break with traditional time, accumulate time or are only temporal. All these ideas apply to the car which serves as a microcosmic counter-site to the country of the boom in Donovan's collection. The occupants are in a state of crisis, their journeys symbolise breaks in time, time is accumulated in the occupants' memories, and these heterotopias are only temporal and last as long as the occupants travel. Only through the characters' liminal periods and personal moments of crisis, their cars become heterotopias of crisis.

According to Foucault, societies can make existing heterotopias function in different fashions (1984: 5). In Donovan's collection, the car is not only an ambiguous symbol, it is also used in various ways: e.g. as a means of transport, an imagined connection to a person the driver once knew or as a refuge. Furthermore, heterotopias juxtapose in one real space several incompatible spaces (Foucault 1984: 6) (which can figuratively be understood as positions, beliefs and opinions in the short stories), and they presuppose a system of opening and closing that isolates them and makes them penetrable. Besides, they function in relation to all other spaces: they can either be spaces of illusion that expose every real space as even more illusory or they are more perfect and therefore expose other spaces as messy and "ill constructed" (Foucault 1984: 8). Especially the first idea applies to the car when it becomes a space in which crises culminate and characters arrive at insights which reveal that they have clung to lies or illusions.

\section{Liminality, Celtic Tiger Ireland and (Irish) Identity}


In Donovan's literary version of Celtic Tiger Ireland, the characters' situations are far more ambiguous than in classic rites of passage. There are tensions between ideas of progress and backlash since Ireland is "on the road" to become a more open-minded nation but its path is not unambiguously defined. This theme is clearly at the core of Donovan's collection in which characters represent parts of Irish society and therefore function as synecdoches. The liminal period as a period of insecurity and uncertainty is further underlined by the setting located within cars, which become heterotopias of crisis and liminal spaces for a specific time span. They are sites of seclusion for their drivers even though the space of the car is not entirely isolated from society and from other people driving on the same roads. The occupants can be regarded as transitional beings who are often thrown into a sudden state of nothingness and crisis without a clearly defined outcome. This differentiates their liminal period from the classic rituals which have a well-defined or expected outcome such as maturity. In Donovan's stories, the characters' new state is often entirely obscure.

Although the notion of Irishness has often been evoked, it seems to be grounded on myths (Smyth 2012: 135) since a homogeneous Ireland and Irish identity has never existed. This is at least partially due to the fact that identity generally is not fixed but constantly moving; it is repeatedly formed and reconstructed. Still, the idea of a particular "kind" of Irishness, which for example included Gaelic traditions and, to some extent, the Irish language and Catholicism, existed and brought with it a partial isolation (at least until the 1950s) and the exclusion of minority groups (Buchanan 2009: 302). However, these groups have moved from the margins to the centre in recent Irish society and in the literary works labelled New Irish Fiction (Smyth 1997). Ireland has become more open-minded but the fast transition, especially since the 1990s, also seems to have robbed many people of a stable basis when it comes to issues of (national) identity. (Post-) Celtic Tiger writers have been trying to explore and represent "the major mutations of Irish society" immediately before the end of the economic boom and ever since (Mianowski 2016: 5).

Despite being first and foremost an economic phenomenon, the Celtic Tiger has also changed Ireland and Irish society on many levels and the term has become a "powerful cultural signifier for progress and newness" (Buchanan 2009: 300). Still, the sense of a spectacular achievement and of having reached the destination which seemed to prevail in the 1990s may have, somewhat paradoxically, contributed to insecurity. As Declan Kiberd stressed in 1995, "The Irish self ... was a project: and its characteristic was a process, unfinished, fragmenting" (120, emphasis in the original). The 1990s added a new image: "Celtic Tigerhood was an important stage in the construction of postcolonial Irish identity, arguably the first one that was not constructed on 'otherness,' on being anti- or not-British" (Battel 2003: 101). When differences are deconstructed in an increasingly globalised world and cultural practices become transnational, Ireland's self-understanding as a unique country in Europe is also eroded and seems to have to yield to a new or reformed self-image (Buchanan 2009: 307).

Battel is exemplary for many critics who see diverse reasons for caution grounded in the apparent Irish success. Beside the major reservation, "deepening social divisions" (2003: 104), she lists further economic factors but also comments on a nostalgia which expresses society's "unease with transition" because it might have happened too quickly (Battel 2003: 105). The creation of something new goes hand in hand with the destruction of something that was well established and this also had, in the context of the Celtic Tiger, severe effects on Irish people's individual and collective identity.

Finding itself in between the "deadly familiarity' of Irish history" and the promise of a new, yet still authentic, cultural identity, Celtic Tiger Ireland entered a liminal state (Buchanan 2009: 305). Thus, it is almost impossible to describe this "new" Ireland of the 1990s: it cannot be defined in terms of tradition or cliché, but it is also not clearly European or Americanised. 
The following discussion of three of Donovan's short stories revolves around notions of instability and transition and reveals that the characters as well as Celtic Tiger Ireland are depicted as being forced to go through a liminal phase. These stories depict journeys but they also show a stark contrast between symbols of movement and characters that seem caught in a state of paralysis. All of the main characters in "Harry Dietz", "Another Life" and "How Long Until" are in a liminal state of confusion, ambiguity and nothingness and their individual fates have to be read against the backdrop of Celtic Tiger Ireland.

\section{Disorientation: "Harry Dietz"}

Ambiguity and disorientation are embodied most clearly by the old man Harry Dietz, the protagonist of the eponymous short story, who drives from Charleston, Illinois, to Chicago. Gradually, the unreliability of the narrative voice and focalisation is revealed: Harry Dietz, a seemingly average man at first glance, has lost all sense of direction, orientation or purpose. He is relegated to his car, thinking about his family's origin in Ireland, which he imagines as a green, mythical and rural place. In need of stability, Harry turns to his past and to clichés but, paradoxically, the reader eventually realises that Harry's past experiences can actually be held accountable for his mental instability.

The story time spans a single day and begins with the lonely Harry Dietz waking up at the break of dawn. Only wearing a dressing gown and a jacket, he wants to buy some milk and thus drives the short distance to a shop in his Ford Zephyr. On his way home, he turns into a small street because he feels that "the street had pulled him to it" (Donovan 2008: 191). The space and movement of the car soon trigger memories and Harry's brief, unwanted glimpses at past personal crises eventually result in a firm denial of crisis and a retreat into an imagined and idealised past.

The car seems to have accumulated mainly hurtful memories. Harry starts thinking about his former girlfriend Mary Norman, whom he had proposed to in his first Ford Zephyr while cruising the same street. The old man has been driving the same model ever since his father bestowed him with his first car which underlines Harry's inability to let go of the past. In this respect, the car is also linked to another telling symbol: Although Mary broke up with Harry many decades ago and is now married to his employer, he still has her photo clipped to his driver's license. This is a highly symbolic place since his driver's license allows Harry to be mobile and independent in terms of movement. However, the fact that he still tries to cling to his past with Mary leads to his inability to look forwards and start a new relationship.

Harry Dietz becomes lost and suddenly finds himself on bigger roads and eventually on the highway to Chicago. Usually, he does not leave Charleston but "today the paved road invited him like a warm canal" and he is "glad that he'd decided to do it", even though he wonders why he has to drive to feel better (Donovan 2008: 193). The car and the streets seem to be the active entities which decide about his trip and thus appear to have more agency than Harry himself. The reader notices something that Harry does not acknowledge: he is a confused man who tries to escape from reality. This confusion is, for example, also mirrored by his slow but chaotic way of driving. Besides, Harry has lost track of time: he suddenly notices that it is Friday, not Saturday as he had formerly thought. He calls his employer to apologise but it becomes evident later in the story that Harry has actually lost all stability in his life: some weeks ago, he was dismissed for shouting at his boss and accusing him of having "stolen" his girlfriend. Evidently, he has repressed the memory of this incident ever since.

Harry's connection to Ireland becomes most noticeable when he stops to make his phone call at a diner where he meets John. The young man was one of Harry's colleagues some years ago and the conversation they start reveals that both John's and Harry's parents were born in Ireland. Both men do not have a realistic idea of this country as they have never been there. 
Eventually, Harry constructs an image of a mythic Ireland which he then turns into his mental refuge. While he talks about a green country, castles and dancing at the crossroads, John at least knows that "something has changed in the country" (Donovan 2008: 197). Harry's imagination is not only rooted in the past but also combines various Irish stereotypes to construct his own image of his country of origin. Nevertheless, this short passage is reminiscent of Ireland's fast progress and its "unprecedented economic miracle" (Cardin 2014: 161) that seems contradictory to the stereotypical rural and stagnating Ireland which Harry still tries to conjure and to appropriate.

Hence, his turn towards an inexistent Ireland and the appropriation of an Irish cliché identity only emphasises Harry's identity crisis. He tells the people he meets "I'm from Ireland" (Donovan 2008: 219) and thereby emphasises his longing for a stable identity. To Harry, Ireland symbolizes stability and a fixed tradition and value system. This idea is as ironic as the collection's title: Donovan's characters, especially Harry, are not "grand" and Ireland at the turn of the millennium was not stable and traditional. Unaware of this, Harry wants to go to Ireland with John because "[1] astly he had run out of life, the emptiness was pouring into his head" (Donovan 2008: 198). As stressed in the initially quoted statement by Bâdalescu, a journey generally signifies movement but Harry's (planned) journeys only cause him to delve deeper into a painful past, full of memories of Mary Norman and his dead father. While driving, Harry increasingly loses himself further, not only in terms of physical orientation, but also with regard to mental sanity. When he finally arrives in a city unknown to him, Harry has become scared and paranoid. Thus the car's movement does not symbolize progress but underlines his journey into the past and towards further confusion and loss instead. Eventually, it becomes evident that the father's Cold War precautionary measures can also be held responsible for Harry's mental state. He finally loses grip on reality when he imagines a Russian attack and the beginning of a nuclear war.

Since Harry is unable to move on psychologically, he tries to cling to a past identity instead. He does not have an aim and rejects to let go of what he is used to and therefore, there is no positive outlook for him. This is also symbolised by the material items he loses: At first, John steals Harry's wallet and jacket so that the Ford is the only possession left. This heterotopia of crisis is an illusory space which symbolizes accumulated time and Harry's break in time when he does not remember the week day and the loss of his job. His car and the journey made in it render visible that Harry's life is an illusion. He is actually thrown into a state of nothingness; ambiguity and confusion do not clear away but increase. Eventually, he even loses his car and sense of location while wandering around. Thus, he possesses nothing, just like Turner's transitional beings.

Throughout the narrative, Harry does not want to acknowledge his liminal state of confusion and nothingness although the people he meets ask him if he is lost (Donovan 2008: 216). Harry's random driving and his insistence on being on his way home (Donovan 2008: 215), when he does not even know the name of the city he is in, only emphasise his disorientation. His liminal period could be a stage of reflection but Harry refuses to reflect on his current situation. Even though these people directly recognize and tell him that he is a "whole lot of lost" (Donovan 2008: 216), Harry cannot admit this and claims that "[ $t]$ he city was getting lost" (Donovan 2008: 225) instead.

Eventually, Harry has reached a state of complete isolation and seclusion which has already begun in his apartment but only becomes manifest in the heterotopian space of his car. This countersite represents a place of retreat which is the last spatial refuge Harry loses. Harry is no longer a member of society at large or the microcosms he tries to enter. In contrast to Turner's rites of transition, there is no positive new state that Harry can hope for. Instead of facing a new situation and trying to start anew after the loss of his job, Harry retreats into the 
past. Reading this character's story as a reference to Ireland, the retreat seems to symbolise the worst imaginable outcome of a liminal state evoked by the Celtic Tiger.

Furthermore, the notion of time provides a connection between Harry's life and Irish society's relation to its history. Many critics have repeatedly emphasised Ireland's obsession with the past and also accused Irish writers of dealing too much with the past and thereby neglecting the country's present and future (Buchanan 2009: 307; Patten 2006: 259). Hence Harry's obsession with the past seems to mirror Ireland's; it becomes obvious that he will not emerge from his liminal state as long as he does not acknowledge and embrace the changes that have occurred in his life. The same seemed to hold true for Ireland in the 1990s. Buchanan explains that the country's new globalised context forced "the nation away from the static confines of its own 'unique' history" (2009: 307). However, the departure from well-known symbols of Irish identity is not without negative effects and risks, which also becomes clear in Donovan's other short stories discussed in this article.

\section{Disruption: "Another Life"}

In contrast to "Harry Dietz," "Another Life" is set in Celtic Tiger Ireland which is presented as a country of immigration and mobility. ${ }^{5}$ Through the protagonist Mary Connolly, an elderly woman who has to face a changed country and simultaneously to re-evaluate her own past, Donovan evokes the image of a new country which stands in contrast to its own past of silence and paralysis.

After her husband Paul's sudden death, Mary inherits a house whose existence she had formerly not been aware of. The journey at the centre of this short story is Mary's trip from Listowel to Oranmore, Galway, in Paul's 1963 Morris Minor. There, she finds the house on a "well-kept and prosperous street" (Donovan 2008: 136) and in the bedroom, she sees the photo of a baby that resembles the man she had been married to for 31 years. The discovery of Paul's double life, and especially the existence of a child, unsettle Mary and coerce her into questioning her whole life.

Mary and Paul always wanted to have children but Mary never became pregnant. She states that in Ireland in the 1960s, people were "too embarrassed to go beyond mentioning it to the doctor" (Donovan 2008: 135). Even though married, Paul and Mary led incompatible lives: she tried to escape from reality by reading romance novels while Paul was frequently absent due to business trips. Mary's preference for a calm life stood in juxtaposition to Paul's, who was a journalist and always happy to be able to leave the town. Hence Mary's trip to Galway is one of the rare journeys in her life and it is crucial that she makes this journey in her husband's car, his "love and joy" (Donovan 2008: 133). Mary has only driven Paul's car twice in the past two months, and she has never left the town in it. Her long trip across the country seems to symbolise greater mobility and independence but it is partially forced and also first catapults her into her own past. She has to come to terms with the existence of Paul's child and eventually also with the insight that her life has been based on lies, silence and the unconscious decision to refrain from understanding.

Mary feels close and connected to Paul by time and space when she sits in his car seat, drives the way he drove and stands in his house. Paradoxically, she imagines to be reunited with her husband by the things that separated them: the house he kept secret and the car which was his means to escape from his life with Mary. Sitting in the car with her eyes closed, she prepares for the entry: "Whatever she might see in that house ... would not change any of the life they owned together" (Donovan 2008: 136). However, Mary soon realizes that this is not true, that the trip actually tears her away from her dead husband and her memories. The reader notices that Mary wanted to consider her life as perfect, but frequent allusions to her loneliness and her romance novels, which substituted fiction and signs of love for real love, reveal that it was not. 
The situation worsens considerably when she sees the photo in Paul's bedroom. The sight forces her to flee from the house and curl up in the backseat of the car.

Soon the temperature in the car matched the weather outside, and the draughts ran her skin cold. She hugged the coat about her, listening to the streetlights clank overhead in the wind and counting now the times he had gone on trips overnight. She lay on her side and shook, watching the windows. The car was the only place she felt safe, Paul's old car. (Donovan 2008: 140)

This quotation reveals the ambiguity of the leitmotif of the car and points to various contrasts and contradictions: Mary sleeps in the car which becomes her own heterotopia of crisis but she thinks of it as her refuge when she feels incapable of re-entering the house. Thus, it becomes her site of seclusion when she is suddenly thrown into a state of nothingness and thus enters the liminal period. On the other hand, the car also is a symbol of mobility, juxtaposing Mary's rootedness in her wished-for ideal past and her illusion of happiness. Although a remnant of the past itself (it was produced well before the Celtic Tiger), it brings her to a foreign place, to her husband's past and it thereby changes her life. Hence, the interconnected notions of time and space become crucial once more.

Mary finally acknowledges that she has to face change even though she has always loved repetition, "a variation on the same pattern" (Donovan 2008: 135). Even after having returned home, she cannot find solace in her novels anymore because "[t]he long drive was still driving in her" (Donovan 2008: 149). This reveals that even though her physical journey has ended, the aftermaths still show and she cannot return to her old ways. Her husband's death and especially the realisation that she has not really known him put her into a state of crisis, a liminal state in between her old life and the acceptance that future changes await her. Thus, the journey in Paul's car becomes the culmination of her crisis, a process that will eventually transform her even though it is first of all a journey into the past. Only when the idealization of the past is overcome and a critical evaluation takes place, a positive emergence from the liminal state will be possible. This insight can again be linked to Ireland and the demythologization of its past and its heroes by the writers of New Irish fiction (Skloot 1999: c; Tóibín 1993: n.pag) who, according to Gerry Smyth, engaged in narrating "the nation as it has been and is, rather than how it should be or might have been" (1997: 177).

Mary's trip marks the entrance into a new self-understanding. Her stage of reflection, confusion and sudden nothingness are symbolized by her retreat into the car, her fall in a bakery and her sudden inability to remember where she has parked the car. This car is her own heterotopia of crisis which only exists during this one crucial journey and which seems to have accumulated the essence of Paul's secret life. Its space and movement link Mary and Paul, although Paul used it to lead his double life. Therefore, the positive symbolic meaning it has for Mary is illusory and it eventually forces her to realise that her whole life has been even more so. However, this insight can actually lead to a new state. Although she has to face a hurtful transition, she appears to be able to overcome it and reappropriate her own past and life. Mary thus stands in contrast to Harry Dietz, who does not seem to have a chance of overcoming the liminal period, since he cannot embrace change in order to draw profit from it.

\section{Disintegration: "How Long Until"}

"How Long Until" portrays a very modern and new Ireland but it simultaneously critically questions Ireland's status and national identity by revolving around the loss and disorientation of the main characters Brenda and Peter. They are a couple in their early thirties, married for four years and now driving to Galway in order to visit Brenda's parents. "How Long Until" 
also centres on a particular moment of crisis, which is a dispute about loyalty and betrayal caused by Peter's question "[i]f I died tomorrow, how long would you wait until you did it with someone else?" (Donovan 2008: 18). Peter feels compelled to ask this question when they are driving past an advertisement for life insurances. There seems to have been a seething crisis they managed to avoid before the journey, but the car is a small space they cannot escape from and this fuels the intensity of their argument.

The development of their argument is reflected by their journey. Besides, the language used in this passage is especially significant since it renders the oscillation between movement and paralysis obvious. It is a bank holiday weekend in June and due to heavy traffic, the cars only move in "small jerks," "stopping and starting" (Donovan 2008: 19) like the couple's conversation. Once asked, Peter's question does not disappear again: "he saw it move up closer, intent on staying in the rear-view mirror" (Donovan 2008: 19). Brenda, after having been quiet for a while, starts talking again when the road becomes narrower and Peter cannot overtake a bus. They are stuck behind an obstacle they cannot overcome, both with regard to their journey and their problems. Finally, Brenda confesses that she thought about sleeping with other men when Peter was away on buying trips and after a while "what she'd said overtook him" (Donovan 2008: 22).

The sense of having come too far too quickly is most clearly mirrored in the life of this couple, who are part of "an upward class of nouveau riche whose major concern is the accumulation of wealth" (Cardin 2014: 165). In his paper on national identity after the Celtic Tiger, Smyth also stresses that suddenly people could afford to buy "more stuff" so that "Ireland became a bastion of conspicuous consumption" (2012: 132). Peter and Brenda try to live on the fast lane but despite the ability to purchase goods and to travel, they seem to get stuck repeatedly. With regard to the problems they have to face in their marriage they are paralysed and insecure and their apparent happiness is exposed as illusionary during their journey. Peter asks Brenda "We're speaking the truth here? We're happy, aren't we?" (Donovan 2008: 26), and the very need to voice this question brings about the revelation that they have so far only pretended to be happy. Smyth explains that "Ireland's great economic miracle was built upon very, very shaky foundations" (2012: 133) and the same holds true for Peter and Brenda. Their relationship is increasingly revealed as instable and they are not contented although they seem to lead what is commonly considered a good life. They are "both working with their own careers, doing well, money in the bank, shopping trips to New York" (Donovan 2008: 24). Brenda and Peter try to live up to an imagined "true" modern Irish identity, which is basically a Disneyland image modelled on an American cosmopolitan consumer culture. ${ }^{6}$

In this context, the consideration of the already briefly mentioned paradigm of transnationalism adds further insights. Transnational texts "transform the scope of the national literatures to which they belong and [push] beyond national boundaries to imagine the global character of modern experience, contemporary culture, and the identities they produce" (Jay 2010: 9). This paradigm contrasts Ireland's past protectionism and its status as a unique nation in Europe with its image as an entirely European and wealthy country, since it asks for a cultural identity that is not modelled on difference but on similarities. The challenge is the construction of a new identity which finds itself in between nostalgia and stability, on the one hand, and modern consumer society and its attractions, on the other hand. This newness of the Celtic Tiger years is, at a cultural level, "the actualization of the promise of globalization that conflates what a culture once thought was only possible with an immediately achievable reality" (Buchanan 2009: 306). This actualization, however, is not simple but demands the adjustment and the engagement of those who face it.

Brenda and Peter have to live up to these challenges of Celtic Tiger Ireland, and the couple is Donovan's most obvious synecdoche of an Ireland which started to run before it learned to walk, trying to come to terms with the past but still too timid to face all problems. 
This is also mirrored in Peter's behaviour when they finally reach the hotel they want to spend the night in: lying on the bed, half watching, half listening to a porn movie, he imagines his wife. However, when Brenda comes in again, "[h]e kept his eyes closed" (Donovan 2008: 33). Furthermore, he thinks about a better reaction to the advertisement he saw: "Better never to have said anything, to have let it go and thought about it instead at three in the morning like everyone else" (Donovan 2008: 23). This quotation illustrates the general avoidance of problems and Irish society's (former) ethics of silence. Besides, this silence connects the young couple to the older generation, represented in Donovan's collection by Mary and Paul, who also did not talk to each other and thus could not solve their private problems. Even in a new kind of society, personal problems remain the same at the core.

While driving the remaining few kilometres to Brenda's parents the following morning, Peter longs for peace and safety. However, by asking his question, he has eventually crossed the border to a liminal state. Both Peter and Brenda finally have to acknowledge their insecurity and the nothingness that their marriage has been relegated to. They have entered a liminal state, but their confrontation could have a positive outcome even though their juggling with their factors of existence causes anguish, insecurity and pain since Peter's and Brenda's minds, expectations and needs signify incompatible spaces. Finally, having reached Brenda's parents' neat house, they have arrived at their destination and at an insight: they have to acknowledge that they are not happy. Even though they seem to be able to overcome their liminal period and enter a new phase, it is still questionable if their transformation will be complete. They have entered this liminal period together and have been forced to face their problems, so they can be "born anew"; either as solitary persons, leaving this period and space separately but more aware of themselves and their needs, or as a stronger couple.

\section{Conclusion}

Donovan's short stories present various levels of change and essentially connected personal and national issues. Harry Dietz is obsessed with his past and desperately clings to it which only worsens his crisis; Mary is reluctant to accept her new circumstances and the need to re-evaluate her past; and Brenda and Peter are disoriented and unsure what kind of hold to turn to, even though their insight might enable them to emerge from the liminal period to meet a more optimistic future. This liminality and its various possible results do not only apply to individuals, but also to national identity and people's position in a new society structure. In this regard, Donovan's Country of the Grand essentially is a book about Ireland and Irish identity during the Celtic Tiger years. This term and time marked "Ireland's passage into a new historical paradigm, an upheaval in the material reality of the nation that redefined the limits and borders of what could, or should, be considered Irish" (Buchanan 2009: 300).

These entangled aspects have been discussed by focusing on the car as a liminal space and heterotopia of crisis. In the short stories, it does not only cross county boundaries but also boundaries between past and present or safety and insecurity. Even though cars generally symbolise modernity, transition and movement, there are many old cars in Country of the Grand. Besides, by juxtaposing cars and their occupants' states of mind, the destinations and aims they reach or do not reach, this symbol becomes and remains ambiguous throughout the whole collection.

Generally, liminality is linked to transition and progress and the short stories analysed above beautifully connect these aspects to moments and heterotopias of crisis. The interconnection between the liminal period and the Foucauldian heterotopia yields various and multifaceted insights with regard to the dynamics and interrelations of a space which remains the same (the inside of the car), a movement from one point to another (the physical movement of both the 
car and its occupants) and the characters' identities and frames of mind which are linked to disorientation, disruption and disintegration.

Due to the liminal period entered by the drivers and passengers, the car becomes a heterotopia of crisis which is only temporary but still marks a crucial space and period in the occupants' lives. The characters represent average people from various classes and generations in a society that has an ambiguous relationship to its past; they are the new "lonely voices" that partially depart from Frank O'Connor's controversial (but still frequently evoked) theory of the Irish short story. These characters are individuals with individual fears and painful experiences but they can also be regarded as synecdoches of a society in crisis and of the liminal state of a country which seems to have overtaken itself.

The contrast between paralysis and the cars' speed is one of Donovan's most crucial means to develop various layers of meaning in his stories. Bertrand Cardin reads Donovan's collection as a warning of the loss of traditional values in Celtic Tiger Ireland and thus of a deterioration of Irish identity (2014: 107). However, even though Donovan's stories can be read as narratives about a crisis in the midst of an economic improvement which coincides with a period of disorientation, they are more than mere warnings. Instead, they rather display the problematic and entangled nature of cultural and individual identities and political or economic phenomena.

Furthermore, Donovan's characters try to avoid thinking about possible future hardships that might begin to take root in their present circumstances. The Celtic Tiger, however, culminated in a financial crisis and its beginnings seem to shine through in Donovan's ironic and often bleak collection. The stories seem to stress that the project of the Irish self is indeed not finished but still continuing. This does not only hold true for the Celtic Tiger years but even and especially for the time of the crash that followed the boom (Smyth 2012: 136). The New Irish Fiction of Celtic Tiger Ireland participated in the process of overcoming taboos and silence. Many Post-Celtic Tiger writers continue this process and even seem to be more concerned with Ireland's present problems and possibilities (Mianowski 2016).

The insecurity depicted in the short stories may lead to a positive result and turn into a new self-understanding. Irish society has already changed, it has opened up and has at least partially disentangled itself from the latest (world economy) crisis. Nevertheless, figuratively speaking, it is debatable if it has already left its liminal period. In Donovan's The Country of the Grand, it has not done so yet. Moving cars and newly built motorways enable further movement and progress but as long as the occupants are in a state of crisis, this does not suffice to reach a destination in terms of identity. Donovan's characters are as unsettled as their country; they belong to a society which is portrayed as moving too fast to keep up with its own pace. They are still h(a)unted by their own past and their own or other people's expectations. Although they reach their physical destinations, they never arrive anywhere safe, they only arrive at painful insights that might mark the end of their liminal periods when they (are forced to) leave their heterotopias of crisis - with uncertain results and effects.

\section{Notes}

\footnotetext{
${ }^{1}$ Even though it is commonly accepted that Ireland's economic status changed thoroughly at the end of the twentieth century, it must be mentioned that not every Irish citizen profited from the economic boom. Drawing on research conducted by Fintan O'Toole, Gerry Smyth goes even further and questions Ireland's status as a wealthy country during the Celtic Tiger years. He explains that cash was mistaken for wealth (2012: 135) and even claims that "Celtic Tiger Ireland remained in some key respects a deeply underdeveloped country" (2012: 136). For my article, however, the most crucial insight is that the Celtic Tiger contributed to a crisis of national and cultural identity when well-established elements of what is called "Irishness" were questioned and even partially broke away when Ireland became seemingly more comparable to other EU members.
} 
${ }^{2}$ Bertrand Cardin further elaborates on the title and the collection's epigraph ("Frailty, thy name is man") in his article, commenting on the paratexts' parodic and ironical dimensions (2014: 160).

${ }^{3}$ Galway is located in the west of Ireland, a part of the Republic that is commonly associated with traditional and rural Ireland. This symbolic meaning is also very prominent in James Joyce's "The Dead" (first published in Dubliners in 1914) which can still be regarded as one of the most famous Irish short stories.

${ }^{4}$ In later works, Turner distinguished between liminal and liminoid rituals (Turner 1982, see also Hetherington 1996: 36). However, this article focuses on liminality in relation to heterotopian spaces and Celtic Tiger Ireland only. Although Turner's liminoid rituals might also partially apply to Donovan's characters, the idea of "play" is too much foregrounded in this second class of rituals. Furthermore, liminoid rituals "develop apart from the central economic and political processes" (Turner 1982: 54). Thus, the concept of liminality is more helpful in connecting individual literary characters to the collective notion of Celtic Tiger Ireland.

${ }^{5}$ For example, Mary lives next to an Indian couple and meets a Polish girl (Donovan 2008: 132; 136). The very presence of these immigrants alludes to Ireland's new status as a country attractive to immigrants. This topic is prominent in Donovan's collection (especially in "The Summer of Birds", which also deals with racism and xenophobia). The best known work of fiction dealing with a new multicultural Ireland might be Roddy Doyle's short story collection The Deportees (2007).

${ }^{6}$ This short story is only one of many in Donovan's collection which could also be read in terms of Baudrillard's concept of the simulacrum. Mary, Brenda and Peter, for example, "substitut[e] signs of the real for the real itself" (Baudrillard 1988: 167).

\section{Works Cited}

Bâdalescu, Dana. 2012. "Heterotopia, Liminality, Cyberspace as Marks of Contemporary Spatiality" The Round Table. Partium Journal of English Studies. http://www.theroundtable.ro/Current/Cultural/Dana.Badulescu_Heterotopia,Liminality ,Cyberspaceas_Marks_of_Contemporary_Spatiality.pdf [retrieved: 31/10/2016]

Battel, Róisín Ní Mháille. 2003. “Ireland's 'Celtic Tiger' Economy”. Science, Technology, \& Human Values 28.1. 93-111.

Baudrillard, Jean. 1988. "Simulacra and Simulation." Selected Writings. Ed. Mark Poster.Stanford: Stanford UP. 169-188.

Buchanan, Jason. 2009. "Living at the End of the Irish Century: Globalization and Identity in Declan Hughes's Shiver." Modern Drama 52.3. 300-325.

Cardin, Bertrand. 2014. "Country of the Grand by Gerard Donovan, or the Chronicle of a Collapse Foretold." Journal of the Short Story in English - Les Cahiers de la Nouvelle Vol. 63 : 159-173.

Donovan, Gerard. 2008. Country of the Grand. London: Faber and Faber.

Foucault, Michel. n.d. (1984). "Of Other Spaces. Heterotopias." http://web.mit.edu/allanmc/www/foucault1.pdf [retrieved: 25/11/2016]

Gilsenan Nordin, Irene and Holmsten, Elin. 2009. "Introduction. Borders and States of InBetweenness in Irish Literature and Culture". Liminal Borderlands in Irish Literature and Culture. Eds. Irene Gilsenan Nordin and Elin Holmsten. Bern: Peter Lang. 7-13.

Hetherington, Kevin. 1996. "Identity Formation, Space and Social Centrality. Theory, Culture \& Society 13.4. 33-52.

Jay, Paul. 2010. Global Matters: The Transnational Turn in Literary Studies. Ithaca, NY: Cornell University Press.

Kiberd, Declan. 1995. Inventing Ireland: The Literature of the Modern Nation. London: Vintage.

Mianowski, Marie. 2016. Post Celtic Tiger Landscapes in Irish Fiction. New York: Routledge.

O'Connor, Joseph. 2008. "Riding the Celtic Tiger." The Guardian. 9 August. https://www.theguardian.com/books/2008/aug/09/fiction1 [retrieved 30/11/2016] 
Patten, Eve. 2006. "Contemporary Irish Fiction." The Cambridge Companion to the Irish Novel. Ed. John Wilson Foster. Cambridge: Cambridge University Press. 259 - 275.

Skloot, Floyd. 1999. "Irish Myth-Making and Myth-Breaking: A Star Called Henry by Roddy Doyle." Sewanee Review Vol. 107. 4: c - civ.

Smyth, Gerry. 1997. The Novel and the Nation. Studies in New Irish Fiction. London: Pluto Press.

2012. "Irish National Identity After the Celtic Tiger." Estudios Irlandeses, 7. 132-137.

Tóibín, Colm. 1993. "New Ways of Killing Your Father". London Review of Books. 18 November. $\quad$ http://www.lrb.co.uk/v15/n22/colm-toibin/new-ways-of-killing-yourfather [retrieved 09/01/2017]

Turner, Victor W. 1999. "Betwixt and Between: The Liminal Period in Rites de Passage." Reader in Comparative Religion. An Anthropological Approach. $4^{\text {th }}$ ed. Eds. William A. Lessa and Evon Z. Vogt. New York: Harper and Row. 234-243.

1982. From Ritual to Theatre. The Human Seriousness of Play. New York: PAJ Publications.

Received: 2 November $2016 \quad$ Revised version accepted: 3 February 2017

\begin{abstract}
Alessandra Boller is currently working as a research assistant and lecturer at the PhilippsUniversity Marburg, Germany. In 2016, she completed her PhD with a thesis on the re/deconstruction of human exceptionalism in selected dystopian novels and films. She holds a Bachelor's and Master's degree in English literature and culture from the University of Siegen, where she has also worked as a lecturer for several years. Among her recent publications are Dystopia, Science Fiction, Post-Apocalypse: Classics - New Tendencies - Model Interpretations, a collective volume of essays which she edited together with Prof. Dr. Eckart Voigts, and an article on the ethics of silence in Roddy Doyle's The Women Who Walked into Doors.
\end{abstract}

